Int. Arch. Allergy 1969;36(suppl 1):1-5

\title{
Contents, Supplement 1, 1969
}

Thanks to an agreement reached with the World Health Organization, with the enclosed annex we can give the readers of our journal the opportunity to become aquainted with the Technical Report Series, No. 423.

We should in this instance like to ask you in your bibliographies to refer to the 'World Health Organization, Technical Report Series, No. 423' or to the annex in 'Int. Arch. Allergy, Vol. 36, No. 6 (1969)'.

This report contains the collective views of an international group of experts and does not necessarily represent the decisions or the stated policy of the World Health Organization.

World Health Organization

Technical Report Series

No. 423

Cell-Mediated Immune Responses

Report of a WHO Scientific Group

World Health Organization

Geneva

1969

Report of a WHO Scientific Group

3

Contents

Introduction 7

Source of Competent Cells in Cell-Mediated Immune Responses

Thymus and Bone Marrow Relationships

8

'Peripheral Sensitization' 9

Dissemination of Cells 9

Blast Transformation of Lymphocytes

3. Delayed-Type Hypersensitivity Reactions

10

Tuberculin Reaction 13

Types of Antigen-Producing Delayed Hypersensitivity Reactions

14

Changes Occurring in Lymphoid Tissue during the Development of Sensitivity

Systemic Manifestations

16

Immunological Specificity

17

Passive Transfer

18

Inhibition of Macrophage Migration as a Correlate in vitro of Delayed-Type Hypersensitivity 20

Application of Cell Migration Techniques to Clinical Problems 25

4. Toxic Effect of Lymphocytes on Target Cells in vitro 
Assay Systems

Different Model Systems

Mechanisms

General Comments

The Role of Passively Administered Antibody in Increasing and Decreasing Cell-Mediated Immunity 35

Simulation of Cell-Mediated Immunity

The Role of Complement 37

6. Relevance of Cell-Mediated Immunity to Pathogenesis

Destruction of Neoplastic Cells

Graft-versus-Host Reaction

4

Cell-Mediated Immune Responses

Role of Cell-Mediated Immunity in Autoimmune Processes

Role of Cell-Mediated Immune Responses in Infectious Diseases

7. The Modification and Control of Cell-Mediated Immune Responses

Antigen-Induced Depression of Cell-Mediated Immunity (Tolerance) ... 50

Antigen Competition 52

Adjuvant-Mediated Depression of Delayed Hypersensitivity

Physical and Chemical Immunosuppressive Agents 52

Suppression of Cell-Mediated Immunity in Certain Disease States

8. Conclusions

54

Select Bibliography

57 Report of a WHO Scientific Group

5

Scientific Group on Cell-Mediated Immune Responses

Geneva, 8-14 October 1968

Members 1

Prof. B. Benacerraf, Head, Laboratory of Immunology, National Institute of Allergy and Infectious Diseases, National Institutes of Health, Bethesda, Md., USA (Chairman) Dr. G.

Biozzi, Director of Research, National Centre of Scientific Research, Institute of

Immunobiology, Hôpital Broussais, Paris, France Dr. B. R. Bloom, Assistant Professor, Department of Microbiology and Immunology,

Albert Einstein College of Medicine, New York, N.Y., USA (Rapporteur) Dr. T. Brunner, Swiss Institute of Experimental Cancer Research, Lausanne, Switzerland Dr. J. R. David, Assistant Professor of Medicine, Harvard Medical School, Robert B.

Brigham Hospital, Boston, Mass., USA Dr. P. G. H. Gell, Professor of Experimental Pathology, The Medical School, University

of Birmingham, Birmingham, England Dr. J. Johanovsky, Director, Research Institute of Immunology, Prague, Czechoslovakia Dr. P. Perlmann, The Wenner-Gren Institute, University of Stockholm, Stockholm,

Sweden (Vice-Chairman)

Secretariat 
Dr. G. L. Asherson, Reader in Immunology, Department of Bacteriology, The London Hospital Medical College, London, England (Temporary Adviser)

Prof. H. Fischer, Director, Immunology Department, Max Planck Institute for Immunobiology, Freiburg i. Br., Germany (Temporary Adviser)

Dr. H. C. Goodman, Chief, Immunology, WHO

Dr. A. Szenberg, Medical Officer, Immunology, WHO (Secretary)

Dr. J. L. Turk, Department of Immunology, The Institute of Dermatology, St.John's Hospital for Diseases of the Skin, London, England (Temporary Adviser)

1 Unable to attend: Dr. B. D. Brondz, Dep $3 / 8$ tment of Virology and Immunology of Cancer, Gamaleja Institute of Epidemiology and Microbiology, Moscow, USSR. 